\title{
Performing the Public: Theatres of Power in the Middle East
}

\author{
Charles Tripp
}

\section{Introduction}

The uprisings that swept across much of the Arab Middle East during 2011 and into 2012 have been powerful reminders of the fragility of political order. One dictator after another fell to the mobilized public after years of seemingly unshakeable rule in a serial drama that continued for much of the year. This apparent break with decades of routine and allegedly resilient authoritarianism calls out for explanation. It provides an opportunity to think about why some regimes were so vulnerable to the kinds of protests that erupted. Indeed, one of the most fruitful times to study the workings of power is when the "normal" is being challenged, when the conventions of everyday performance break down and fail to hold the audience. Aspects that might have been taken for granted or overlooked are now revealed as part of the architecture and artifice of domination-the carefully constructed theatres where scripted roles are played out, reinforcing established hierarchy and order. It is at moments of upheaval that one can form an impression both of the resilience of the established repertoire, and the resources on which those who would challenge it may be able to draw. Performing resistance is in this sense part of the intended reordering of power itself, bringing a new order into being through an appropriation of the spaces and the discourses that appeared hitherto to exist only for the benefit of established power.

It is the intention of this article to reflect upon some of these performances and, in doing so, to reflect on the productivity of an approach that emphasizes the performative aspects of the political. Implicitly, therefore, this is an agency-centered account of the political. It is based upon the assumption that power relations are in the 
final analysis relations between actors, despite the frequent attempts of one party to deny effective agency to the other, often preventing the other from even imagining the possibility of autonomous action. Such a situation makes it all the more important to understand the norms, the institutional structures, the rhetoric, and the incentives that create the enabling environment of both oppression and resistance. It is here that an understanding of the performative in defining agency becomes central since it sees performance not as extraneous but rather as implicated in the very notion of political behavior itself as a social act.

The theatres in which those actions take place, as wide or as narrow as human experience itself, form the structural settings in which self-representation and the performance of roles are played out. These can appear unscripted, yet may follow well-structured conventions and have been features of power everywhere. When performed in the service of established hierarchies and political orders, they are implicated in the ubiquitous claim that this is part of the natural order of things. Thus, a specific political project or set of exclusionary arrangements can be represented as the supposedly validating tropes "tradition," "national identity", "human nature," or "progress." This is as true for the neo-liberal project, as it has been for the socialist ideal, and for one that asserts the primacy of religious revelation as the basis of social order.

These roles are defined and constructed, and, in being performed, help to reproduce the subject and thus to reproduce the political order. In this sense, these processes lie at the center of understandings of power. The implications, therefore, for the critical study of power are twofold (at least). In the first place, they lead to an investigation of the nature of the performative in the constitution of power and the ways this may be shaped by forms of mutual recognition. Such an investigation 
naturally requires some account of the ontology of performance as a basis for explaining why power is constituted as it is in any given setting. Second, this leads into the specific investigation of what can be termed the dramaturgy of political performance. This refers not simply to the general conditions that create political possibility, but the particular forms and techniques that produce the drama that has the power to enchant and to mobilize in practice.

It is in this sense that the uprisings of 2011-12 across the Arab states, both in themselves, but also in their antecedents and their still uncertain consequences, afford us an opportunity to understand how new orders come into being, even in situations that had seemed to provide space only for performances that reinforced and validated the status quo. Focusing on such a way of approaching power and its underpinnings might help us to understand the ways in which power has been constituted, projected, received, accepted, and challenged in specific circumstances, contributing to a critical reading that embraces the "field" in its broadest sense. In particular, the events of 2011 brought into being a mobilized public, constituted in large part through performances that gave it new meaning. These did not come out of nowhere. On the contrary, there were enabling conditions of both a material and an imaginative kind that had long been in the making, unconsidered by those in power, perhaps because of the very nature of the complacency and the contempt that colored their view of their subject peoples. Nevertheless, something happened in the momentous months of 2011 that brought these strands together and transformed a newly energized and conscious public into a collective force that could not be ignored and that in some cases overturned the existing political order.

\section{The Ontology of Performance and Performative Power}


In seeking to understand the relevance of the ontology of performance in the constitution of the political, two main themes of argument will be developed. The first will explore the idea of the habitus as a structure that is both formed by and formative of the subject, generating the social and economic roles that are both expected of and internalized by the agent, reproduced and reinforced by the agent's performances. It is thus a concept that is deeply implicated in ideas of performance and the ways in which certain forms of bearing, speech, and behavior have been regarded as acceptable or unacceptable, reasonable or unreasonable. It is also something that is constituted by continuous performances, by iterations and articulations and, in turn or reciprocally, it also shapes the performing subject, providing an act's context of intention. In this sense, therefore, it is also at the heart of power, the internalization of its order and the externalization of those intentions that may reinforce, or may indeed undermine a given dispensation. ${ }^{1}$

However, by exploring the possibilities of the subversive changes that may be brought about through the same apparent set of social and intellectual formations that also reinforce the established order, the notion of the habitus should also be understood to have a potential for encompassing, even encouraging change. Sometimes criticized for its structural rigidity and thus its tendency towards a determinism that leaves little space for the agency of those shaped by it, habitus can nevertheless be seen to contain within it the notion of mutual constitution, not simply one-way determination. This is particularly significant when reflecting on the ways in which the uprisings of 2011 resonated across the region-a region that, on one reading, could be said to have been in the grip of powerful, ruthless, and repressive political regimes. Yet it was in just such a setting, although admittedly with different outcomes, that people across the region made common cause and saw in the struggles 
of their neighbors the potential of their own resistance. In doing so, they also created across the region a common feeling of the need for change and a sense of their own power to bring it about.

Thinking of performance in such settings opens up a number of questions relevant to understanding the full context and effect of power differentials between elite and subaltern. It can provide examples of the ways in which the elite itself is constituted by performances targeted at each other and at worlds beyond its shifting boundaries-with all the contradictions and dilemmas this engenders, as well as the possible implications for the techniques of performance. It also obliges one to take into account those whose roles have been written for them and whose complicity is assumed, but who might have very different ideas about the kind of performance in which they are involved, with potentially serious implications for the configuration of power. $^{2}$

Such a turn to the performative avoids the danger of attributing to a small group of individuals-possibly even to one person-an all-knowing and all-seeing capacity. Ironically reflecting the form of self-representation so beloved of these elites, there has been a tendency in some of the "state-society" literature to suggest that those who hold state power somehow stand outside and above the social and political universe of which they form part, manipulating the players in a detached way, geared only to an unambiguous understanding of their own interests. By seeing elite power not simply as the self-conscious outcome of the ambitions of a small selfselected group, but as part of a larger performance that reproduces power by constituting and reinforcing aspects of domination, one can broaden the analysis of that power. Such an approach thereby encompasses those who are excluded from power, but who are nevertheless very much targeted and involved in the exercise of 
that power and indeed whose subordinate position gives it meaning. They are the political subjects who are assigned specific roles in the performance, both as audience and as players, receiving, but possibly also reworking, the political myths of the dominant order. This may ironically create the space needed to transform such myths into a repertoire of resistance rather than acceptance. ${ }^{3}$

In placing performance at the center of the political order through its power to shape social relations and expectations, the intention is to see it as much more than simply an expression or symptom of some other kind of power, located elsewhere. On the contrary, it may be implicated in the very constitution of political power itself. For example, in Egypt during the last decade or so of the regime of President Mubarak, it was the prime task of the ruling National Democratic Party, led by his son Gamal Mubarak, to spearhead the introduction of neoliberal reforms. These were allegedly going to transform the Egyptian economy in ways that would both satisfy the international financial institutions, and the interests of those in Egypt who stood most to gain from the program of privatization. Central to this project was the idea, but also the theatre, of the market, in which policy makers, investors, and the workforce were all ascribed distinct roles to make the project work. This involved performance both in the sense of acting out roles that would gain international recognition, and with it inward investment and support, as well as in the sense of ensuring that the Egyptians involved at all levels in the process acted out their parts. In other words, it bore all the hallmarks of the unity of action needed to reproduce the attitudes, power relations, and hierarchies associated with neo-liberalism.

However, as the turbulent industrial relations of Egypt during the $21^{\text {st }}$ century showed, the very single-mindedness of the project produced a politics of contention. As in Tunisia, Egyptian workers in the industries targeted for privatization, but also 
officials at various levels of the administration, saw this as a threat to their own interests and even identities and mobilized accordingly. Drawing on repertoires of association that had historical antecedents, but that also were suggested by the very nature of the neo-liberal project itself, they organized in alternative spaces, forming themselves, through performances of difference, defiance, and solidarity, into an identifiable and oppositional set of political actors. ${ }^{4}$ This was not a catalyst of the events of 2011, but it certainly fed into them. It provided the enabling mechanisms for other kinds of mobilization and underlined the importance of the performative in challenging established power.

The emergence of a radical critique of existing power structures, and an indictment of the very order that hitherto has used these very forms and signs as part of its own system of self-maintenance, raises the question of the conditions under which this happens. Surveying the events of 2011 and the years that preceded them, the "rupture" identified by Bourdieu could be applied to the impact of the uprisings themselves, but also to the more gradual processes of contested interpretations and failing conviction that explain why these events had such power at that time. ${ }^{5}$ In this context, therefore, a performative politics was both central to the project of governance, but equally helps to explain the power of those resisting the project. In both senses the performative is at the heart of power relations.

This leads into the second strand of argument, relating to the aspects of performance that lend it power in any given social setting. In many respects, this is closely linked to specific understandings of the nature of the subject that responds to, acts out, and contributes to the production of the performance. The first of these aspects revolves around the aesthetics of performance and the degree to which it speaks to, and thus demands attention be paid to the ways in which enjoyment plays a 
role in the constitution of the subject. Developed at length by Žižek who in turn drew upon Lacanian ideas of subject formation, it nevertheless also provides a link with the writings of Bourdieu and others. They were seeking a greater understanding of the ways in which an "affective politics" may explain the power of social and political practices in ways that elude the more conventional understandings of ideology. ${ }^{6}$

In the light of the events of 2011-12, this may be a particularly fruitful way of understanding the power of uprisings that were clearly not following a path marked out by a defined and historically rooted ideology associated with established political parties and organizations. On the contrary, vast numbers of people in Tunisia came together around the horror of the image of Mohamed Bouazizi as he burned himself to death in protest against the authorities. In Egypt, thousands mobilized around the equally horrific picture of the mutilated face of Khaled Said that formed the centre of the internet campaign "We are all Khaled Said." These were the symptoms, but also the triggers of an affective politics that needed no ideology or party. In what has been well described as the "horizontalism" of the process, organizations certainly played their part in helping to mobilize and solidify the protests-such as the Tunisian UGTT (General Labour Union), independent factory-based workers' associations and even football fans, like the Ultras, in Egypt, as well as professional associations and other groupings in both countries. ${ }^{7}$ However, they themselves were brought together by a solidarity fashioned around a demand for dignity in the face of accumulated years of the hogra of the incumbent regimes. ${ }^{8}$ The performances of defiance and disobedience found their own explosive expression against the increasingly unconvincing performances of state power.

Importantly, these performances of resistance that brought hundreds of thousands, even millions onto the streets across the Middle East, made the re- 
appropriation of public space the focus and the test of their resolve. It both symbolized their confrontation with the old order, but also formed the battleground on which each tested the other. Physically and symbolically, therefore, the public spaces of Middle Eastern cities that had hitherto been reserved for displays of power by the regime became sites for the reclaiming of a public sphere in ways that only differed fractionally from country to country and city to city. It was as if the thousands of assembled protestors could tap into a repertoire that long made sense to them, but that could now be used to exclude and face down the overweening power of regime. ${ }^{9}$ Faced by this, in Tunisia, Egypt, Libya, Syria, Yemen, and Bahrain-as well as on a more limited scale in Iraq-the authorities fell back on violence, with varying outcomes, but with the common intention of removing, even annihilating, the bodies that had so clearly failed to take into themselves the habits of obedience and deference.

This obvious relocation of politics to the public sphere, provides the constitutive link between the subject, the performance, and the spectacle. Whilst the latter has sometimes been treated as a kind of epiphenomenon that simply expresses unequal social relations constituted elsewhere, in the writings of Debord it becomes itself a crucial component in the socially transformative processes of commodification-a "world view transformed into an objective force," with radical implications for the performances that comprise it and for those who are taken to be the chosen audiences and consumers. ${ }^{10}$ However, by articulating this idea of the performative spectacle to the insights originally advanced by Goffman and later developed by Žižek, concerning the role of the Other in the constitution of the self, it reinstates the notion of mutually constitutive agency into the otherwise rather passive and undifferentiated notions of the "consumer", "audience", or "the extraordinary 
inertia" engendered by a habitus in which spectacle and commodification are intimately linked. ${ }^{11}$

By re-appropriating public space, the mass of individuals involved in the uprisings were performing their rights as citizens, reconstituting an activist and mobilized public and thus, through performance, gaining both self-recognition and recognition by others. Furthermore, they were doing so against the dominant power, defining themselves against the Other, as ruler and regime. In fact, these regimes had helped in this production, even if unintentionally. By seeking to make their subjects the passive consumers of the spectacle of dictatorship, they had ironically given them common cause to reject both the spectacle and the multiple performances of arbitrary and often brutal power that underpinned it. ${ }^{12}$

Specifically, this argument helps to throw light on the performative by understanding performance pre-eminently as a mutually constitutive relationship. We perform for others, we comport ourselves, and act aware of the gaze of otherspossibly only of certain designated others-seeking recognition but also a kind of validation of the self. Thus, the Other for whom the performance is enacted becomes a constitutive element of the performing subject in two intertwined senses: first, as the active subject who directly impinges on the performance through approbation, or possibly violent rejection; second, as the imagined and thus internalized recipient of the performer's enactment of the role, shaping through inner projection the styles, idioms, and gestures of the performance. Nowhere was this more evident than in the events of 2011-12. The public was coming into being, but the very performance of it split the audience in many countries. On the one hand, there was the sought for and mobilized approbation of fellow citizens, and some elements of the state apparatus, affirming and reinforcing the new roles that the citizens had taken over. On the other 
hand, as the examples of Libya, Yemen, Bahrain, and Syria showed, it also provoked violent rejection by the powerful in a theatre of cruelty that was intended both to destroy physically and to demonstrate in all its gory detail the price of dissent.

As the uprisings of 2011 unfolded, the power of imitation, of acting out roles and using repertoires adapted from elsewhere became a key feature in the constitution of the activist citizen. This held true not only for the transmission of slogans and tactics from one Arab country to another. It was also the case in the emerging patterns of behavior in Avenue Bourguiba in Tunis, Tahrir Square in Cairo, Taghyir Square in Sana a and the Pearl Roundabout in Manama. Although occurring in very different countries, under otherwise different conditions, the thousands who assembled appeared to feel the same impulse to perform the public and, in doing so, to act in ways that subverted the monologue of the dictatorships. The enacting of an alternative order of things clearly had a powerful effect on those drawn to the demonstrations and occupations. They may have had only a hazy idea of what it was they expected to see or to experience, yet their widespread imitation of those they saw around them through outward performance helped to focus and to transform the consciousness of the subjects. Indeed, in Pascal's inversion of belief and action in the famous dictum that so fascinated Althusser and others-"Kneel, move your lips in prayer and you will believe"-it could be said to have been expressing enduring recognition of the intimate link between performance and the constitution of the self, as well as of the power of habitual performance and iteration in this process. ${ }^{13}$

It is in this context that the idea of the habitus and the performances it conditions and which help to reproduce it can accommodate variable, even subversive patterns of behavior and performances that challenge the order with which it might be associated. Here Rancière's idea of political "subjectification"-the process that 
engenders agency-when deployed in conjunction with the process of "disidentification" can explain the ways in which individuals and groups, hitherto marginalized or allocated subordinate roles in the larger social performance of power, reject these roles. This can lead them to act in ways that might engage with the original script but only in order to assert the right to play roles with radically transformative implications for the established hierarchy. ${ }^{14}$ This in turn, draws our attention to the contours of such performances and to the conditions under which certain kinds of performances succeed in achieving the power to which they aspire, whilst others fail and, in failing, may produce a very different orientation of the political drama.

\section{The Dramaturgy of Performance}

It is for these reasons that it is important to take into account the dramatic conventions surrounding, infusing, or enframing the performance-the dramaturgy of performance. This helps not only to explain common structures, but it can also account for their power, when they "work" and when they fail to do so. It is here in part that one might begin to explain the extraordinary force and coordinated effect of the uprisings of 2011. The fact that events similar to these had taken place over the past decades in many Middle Eastern states, but at different times in relatively isolating circumstances, helped to prepare the ground. Enabling structures, networks, and associations had endured, even if dormant. Equally, the embodied memories of previous uprisings had provided a repertoire familiar to many. It is perhaps not surprising, therefore, that so many people grasped so immediately what it was about in $2011^{15}$ 
However, the combined power of these developments may also be explained, at one level, by the narrative logic of performance as a particular kind of social activity. More specifically, despite its location in a very distinct cultural space, there may be more general structures underlying particular performances that prompt its recognition as a drama, enhancing its narrative and dramatic power. In this respect, it requires an exploration of the frame of the performance that places and dramatizes it within systems of recognition, implying an understanding of the epistemology of framing itself. Here, in the context of the mass protests of 2011, there were the generic and powerful calls for dignity, respect, freedom, and public rights that resonated across the region. But there were also the equally moving statements of intent and volition by individuals caught up in the drama. They responded in ways that gained instant recognition, amplifying what may initially have been a particular protest, but coming together through the poetry, drama, and often humor of the performance to act out and indeed to become the public as a collective body and political actor of immense and diverse political potential. ${ }^{16}$

These aspects draw one's attention to specific areas that help to link the larger questions arising from the idea of the performative in politics, to the specific questions of dramaturgical possibility, showing thereby the limitations on the power of performance in practice. Based on the fundamental structure of drama as a purposeful human activity and the relationship that lies at its core-that between performers and their audience-two such areas suggest themselves. First, there is the setting or stage, both temporal and spatial, that expresses, but also helps form, the relationship between performers and audience. Second, there is the structure of the narrative, as well as its symbolic resonance, its presentation and the nature of the roles that make sense of the performance and give it its power. These factors help to 
constitute this key relationship and to form the subjectivities that interact through drama.

In assessing the events of 2011-12 that comprised mass uprisings and multiple acts of resistance across many of the Arab states, the beginning of any enquiry must revolve around the forces or factors that brought the performers and the intended audience together - in other words, why this grouping, why here and why now? Whatever the nature of the relationship - performers acting out of defiance in the face of established power, or acting to impress upon the outside world the nature and the potential of their cause, or seeking to integrate with those before whose gaze they are performing-it is important to understand the historical and spatial conjuncture. In this case, whether in Tunis, in the cities of Egypt, or of Syria, or of Libya, it was urban public space that became the most meaningful setting for action. The determined reappropriation of the Avenue Bourguiba in Tunis, or Tahrir Square in Cairo, or Arbaeen Square in Suez, or the Pearl Roundabout in Bahrain all conveyed powerful messages about the power relations embodied in and reproduced by these settings, as well as their potential for resistance. It was for this very reason that the Bahraini authorities, having cleared the roundabout of demonstrators in March 2011, proceeded to demolish the monument at its heart, so powerful was its symbolism. Occupation and demonstration thus provided an understanding of the congruence of the roles with those settings. They enabled the political public to come into being through multiple performances in public spaces. ${ }^{17}$

In this sense, performative politics in its constant enactment is also constitutive of the self and the political subject: it involves and, by involving, furthers the construction of identities, interests, and selves. It directs our attention towards the setting that is itself being constantly reproduced and towards the other forces that are 
also working on that setting. In other words, there is very rarely the situation of the "captive audience"-and these other factors can have important effects on the way the performance is constructed and construed. This also ties into the question of the transformative dialectic of self and other in performance and the part this plays in the constitution of the self: we become what we act, and we act before others and their expectations of us, through our expectations of them. This never happens in a neutral environment, but in a setting where power differentials are very much part of the practice and where it could be argued that the interpellation of the subject has initiated the performance. In this respect, it is important to consider the ways in which particular kinds of sites for the staging and framing of performances may be congruent with the systematic evasion of reciprocity, at least in intention. ${ }^{18}$

Some have argued that this has been one of the marked attributes of the "mediatization" of public life: presentation and performance through the visual media have introduced not simply a new, amplified technology of performance (for the powerful, a multi-screen, 24/7 presentation of the Roman triumph), but have created a qualitative shift in the way that performance works and the ways in which a passive, consuming public is constituted. ${ }^{19}$ Yet the events of 2011-12 in the Middle East-and elsewhere, it should be said-would appear to support the argument that whatever the intention, performance cannot in fact ever be purely a one-way street, precisely because of the ontological questions raised at the outset. Thus, whilst power may seek to project itself through the electronic media and to fashion docile, willing, and impressed recipients or consumers, it must itself be partly constituted by them, by their expectations, and by the input of those for whom the performance is intended.

This was made manifest in a number of ways in 2011 . There were the demonstrations in front of media centers that had for so long been associated with the 
regimes' versions of the manufactured public. In Dar'a in Syria, the local building of the state broadcasting authority was burnt down. In Cairo, both in February and, more violently, in October 2011 demonstrators protesting about the lies broadcast by Egypt's state media were confronted by units of the Egyptian army. More insidiously and subversively, the newly mobilized public did not just show itself in the streets, but had already begun to dominate the social media. Using its networks and those enabled by other forms of electronic communication, members of the public became "citizen journalists," both reporting on and filming the events they were witnessing and in which they were participating, as well as commenting on them and helping to mobilize others, amplifying the messages of defiance and resistance. In this sense, the media in all its forms had been transformed into a platform for the portrayal and performance of resistance, giving substance to the mobilized public. ${ }^{20}$

In order to understand the effects of these performances, it is important to examine the idioms and the repertoire involved, as well as the ways in which they are brought together to reinforce the persuasive power of a particular narrative and to amplify its dramatic effect. How do certain performances and dramatic narratives "hook," engage, and mobilize people around a version of the political? In order to understand this and to assess the relationship between the performance and other forms of power one would need to look at the processes of interpellation of subjects, both the performers and those before whom they performed. In some cases, it might be hard to distinguish the two and that may well be part of the explanation. ${ }^{21}$ This is of particular significance in understanding the otherwise puzzling speed, spread, and coherence of the uprisings of 2011, disorganized and leaderless as they apparently were. 
This raises the question of whether there are key elements in such performances that repeat or take up again familiar themes, lending them an impact that depends upon recognition. However, by the same token, familiar performances may be subject to the rules of dramatic decay. Thus, repetition can create the fever of anticipation, as well as the glow of recognition and familiarity. But it can also engender boredom and a cynical distance from the performance. To some degree, this was experienced in the course of 2011 and 2012 in Egypt, when continued public suspicions of the ruling Supreme Council of the Armed Forces [SCAF] led to successive demonstrations and occupations of Tahrir during the course of these months. Quite apart from the increasingly ferocious response by the armed forces to the continued defiance of their authority, the demonstrators also discovered that there was a falling off in the numbers and commitment of the participants. As the mobilized and plural public began to find its multiple voices, some of the issues became more divisive.

In the aftermath of the fall of President Mubarak, some felt that the successors should be given the benefit of the doubt and should not be continually opposed. Furthermore, resistance through similar performances of demonstration and occupation diminished their power. They had become over familiar, paler repetitions of performances that had originally had power and meaning. In addition, the theatre of power was changing, moving away from the public spaces of the city to the public institutions of a revived parliament, an electoral process, and the nominally public administrative apparatus of the state. These were the sites that were to be the main battlegrounds between the emerging popular forces, Islamist and secular, and the entrenched power of the military establishment, as the tense months leading up to the election of President Morsi in June 2012 bore witness. ${ }^{22}$ Different kinds of 
expectations were created, as well as different forms of behavior with performances appropriate to the ill-defined roles of all the players. Those who felt excluded from this process and who yearned for the seemingly more straightforward dramas of early 2011 were still mobilized, but were having to find other ways of acting upon their grievances. This suggests that the success of the performance will be dependent on the relationship with the audience and will require attention to the rules of dramatic timing, phrasing, engagement, and aesthetic appeal, however diverse these aspects may be. ${ }^{23}$

Of course, part of the explanation for the falling off in the numbers of those willing to enact the public in Tahrir and its environs may have been due to SCAF's authorization of extreme violence to clear the square of the demonstrators calling for their downfall. Participants in one kind of performance found themselves confronted by those willing to act out roles to a very different script. By comparison with the violence used by the security forces in Syria, Libya, Bahrain, and Yemen against demonstrators, that used in Egypt was moderate, although in the demonstrations of October and November 2011 some fifty Egyptians were killed by the security forces. However, the question of violence does raise the question about its role in the drama of performative politics, some of the key features of which have indeed been borne out by some of the developments associated with the uprisings in the Middle East during 2011 and 2012.

An important and often productive way of studying and understanding political violence in all its forms is as a performative act, communicative but also theatrical, geared to specific settings and audiences, requiring specific roles and the maintenance of those roles. Political violence in this sense is aimed at achieving certain goals through the amplification of its effect. Indeed, calculating how to 
generate such an effect becomes one of the major preoccupations of those who would use it as an integral part of their political project. Violence in this sense is also constitutive: it helps to construct political publics through the responses to the ways in which violence is represented. In doing so, it shapes the "realities" that frame the debate about the performance of violence, its means and its ends, as well as the norms governing both. ${ }^{24}$

Political violence clearly foregrounds the spectacle in a way that suggests both enjoyment and drama in the reinforcement or indeed in the unsettling of power. These are performative effects, aspired to both by established power and by those challenging the hegemonic claims of established power by spectacularly demonstrating its inadequacy. Political violence as performance makes it a language of power both entrenched and insurgent. In many of the countries that witnessed uprisings in 2011 and 2012 in the Middle East, it was striking that so many hundreds of thousands made a conscious decision to answer this with the performance of nonviolence. In Tunisia, in Egypt, and in Bahrain, but also initially in Yemen, Libya, and Syria the protestors and demonstrators asserted their presence and their power through nonviolent action. Precisely to counter the violence of the state and, it was hoped, to neutralize or at least confuse and split the security forces, as well as to communicate a powerful message of nonviolent resistance, of a people returning to reclaim what was rightfully theirs, the demonstrators occupied public spaces under the ubiquitous chant of "Silmiya! Silmiya!" [peaceful, peaceful]. The performance of nonviolence was thus a key part of their political formation, as well as of their strategies, its techniques studied and communicated from country to country, often codified in instruction manuals such as the Tahrir publication "Kayf tathawwur bi- 
hada 'iah" [how to revolt peacefully], or the advice from the Serbian youth movement Otpor that had helped to overthrow President Milosevic in $2000 .^{25}$

Elsewhere, as the examples of Bahrain, Yemen, Libya, and Syria showed, nonviolent protest was met by ferocious violence on the part of the authorities. They were seeking not merely to clear protestors from public spaces but also to annihilate any form of open resistance, as well as to make an example of those who might be even vaguely connected with opposition, or with towns and villages where dissent had come into the open. In Libya and in Syria, in particular, the violence of the regime's response provoked counter-violence by the protestors. In the Libyan case, this led to a split in the armed forces and the division of the country into two hostile camps, with the insurgents, assisted by massive NATO air intervention, finally overcoming the forces led by the government of Mu`ammar Qadhafi after months of fighting. In Syria, the relentless use of force by a government intent on reasserting its control over the whole of the country, in the face of growing numbers of armed insurgents, led to some 20,000 deaths, mostly civilians, in the space of eighteen months as the country slid into civil war.

In the initial stages of the Syrian uprising the tens of thousands of citizens who came out in protest against their government were clearly determined to sustain and to develop nonviolent means of resistance and civil disobedience. This may have been due in part to a widespread belief that imitation of the methods used in Tunisia and Egypt would produce equally dramatic results against a regime that appeared to be just as well entrenched. The power of the performative example had, after all, been evident across the region in the early months of 2011 . However, there was also a more general concern in Syria about the possible effects of the use of violence against the security forces of the regime. 
Many remembered the terrible example of the city of Hama, much of which had been destroyed by units of the Syrian armed forces in 1982 with the loss of some 10-15,000 lives. They had paid the price for an armed insurrection by the Muslim Brotherhood in the city. The Brotherhood had by then been leading an armed revolt against the regime for four years, despite misgivings within the organization that they were effectively "playing into" an existing theatre or dramatic production of authority and power, dangerously reinforcing it. For a regime such as that of the Ba'th in Syria, violent opposition, both in 1982 and in 2011-12, "made sense" imaginatively and tactically. It fitted precisely into the role that they had assigned all opposition, portraying dissent as nothing more than the work of "armed gangs," fired by fanaticism and manipulated by the enemies of Syria.

In this respect, therefore, the violent resistance was much less disconcerting for the regime than the performance of nonviolence, something that did not enter into the lexicon of the regime and that seemed, therefore, potentially more threatening. It was perhaps for this reason that the peaceful demonstrations of the first months of the uprising in 2011 met an immediately violent response from the security forces. They were trying to disperse and to deter the demonstrators, but they may also have been hoping the change the nature of the performance itself and the stage on which it was to be played out. During 2012 in particular, the transformation of the mass of protestors occupying public spaces into guerrilla bands, making hit and run raids on the security forces, came long after the Syrian government's early claim in 2011 that this was what they were facing by way of opposition. It was as if they had scripted these roles because it was this, not the reinvention and mobilization of the Syrian public, that fitted so well their own political imagination and their own fifty-year long performance. $^{26}$ 
In another respect too, the demonstrators feared the performances in which they might become implicated, should violence become the principal means of expressing opposition. From the outset of the protests in March 2011 they had made a point not only of constituting themselves as a peaceful public reclaiming their rights, but also as a national public of Syrian citizens. Thus the performance of nonviolence was accompanied by performances of national identity and unity. The massed ranks of demonstrators would chant "One! One! Syrians are One!" clearly determined to present themselves as a body of Syrian citizens, a distinctively Syrian public. ${ }^{27}$ This was precisely to counter the other powerful narrative of Syrian political society that emphasized the confessional diversity of the Syrian people, where some seventy percent might be Sunni Muslims, but the remaining thirty percent were Ismailis, Druze, Christians, and, of course, Alawis. The latter was the confessional identity of the ruling clan of the al-Asads, and of many of the senior figures in the regime, especially those associated with the security and intelligence services. Open rebellion in such a system therefore always ran the risk of becoming entangled in sectarian enmities.

The risk was redoubled if violence was to be the main medium of the uprising. Under such conditions, as had happened in the neighboring states of Lebanon and of Iraq, the life and death nature of armed struggle placed a premium on trust. On the one hand it encouraged fears among the minorities that the expression of popular protest was really a disguised bid by the majority community for power. On the other hand, it opened up the suspicion that certain villages, certain urban quarters might be unreliable in the struggle because they were inhabited by people who shared minority status with the regime. In addition to this, there was always the danger of symbolic violence against individuals simply because they came from the Alawi community. 
The regime itself was well aware of these possible fracture lines in the Syrian public and exploited them to their advantage, playing upon the fears of minorities about the disorder and violence that could follow the overthrow of the regime. At the same time, as the uprising gathered strength, the authorities encouraged the sectarian aspect, deploying the Shabbiha [ghosts], an armed militia largely recruited from and clearly associated with the networks of Alawi clans from the Alawi Mountains and the coastal plain. This militia was responsible for ferocious attacks on demonstrators and on dissidents, often imposing collective punishment on entire villages and families. In this respect, as with the use of force more generally, it appeared that the Syrian regime was trying to script a performance that would indeed entwine violence and sectarian hatred. Dangerous and bloody though this was, it was a counter to the protestors' performance of the unity of the Syrian people, and thus more attuned to the narrative that had long reinforced the power of the al-Asad clan.

In this sense, therefore, violence and nonviolence are performances that generate their own power, constitutive as well as destructive, although in very different ways. One of the extraordinary achievements of hundreds of thousands of citizens in Tunisia and in Egypt in 2011 was their success in toppling dictators by nonviolent means, making redundant and therefore neutralizing the coercive powers that the authorities still had at their disposal. In Libya and in Yemen, similar performances had the equally dramatic, although in the end far more bloody effect, of cracking the coercive power of the regime itself, turning its instruments of violence upon each other. In all these cases, however, there was little doubt that the unfolding drama and the spectacle of a mobilized public, performing resistance before multiple audiences, drove the narrative, as it did in Bahrain and in Syria where the outcomes have been very different. 


\section{Conclusion}

The events of 2011-12 in a number of states in the Arab Middle East have been dramatic and moving indicators of the power of ordinary people when mobilized and acting in concert, even against entrenched and ruthless regimes. In their drama and in their capacity to move others far beyond the borders of particular states, or even the region itself, they have demonstrated the performative aspects of politics at their most potent. In doing so, they are a useful reminder of the underlying performative nature of much of political life, not only in its open forms of contestation, but in the establishment and incorporation of the routines by which order is maintained. In this sense, therefore, as a frame for studying both the workings of a dominant order, as well as the potential of its challengers, to understand performative politics is to engage with much more than the visible and the demonstrative.

These certainly form part of the analysis and a crucial part as well, given the key factors of aesthetic and affective display, the repertoire, and the dramaturgical logic in explaining the power of performance in shaping the course of human actions. However, this examination of performative politics goes further than that. It also suggests that it is through performance that identities, social formations, and relations, as well as dispositions, are constituted. It is this that makes an understanding of the performative so central to an understanding of power. In that key relationship reside not only the imagination, norms, and habits that people bring to it, but also the potential to be transformed by it and thus by the performance of the other that may be encountered therein. The outcomes, as the events of 2011 onwards have demonstrated, may be contested, complex, and subversive of the intentions of all parties, but they will be outcomes intelligible to, if not desired by all. The challenge 
for many, and the underpinning of a new round of contestation, will be to ensure that they have the same ability to participate in the changing theatres of power as they seized so dramatically in 2011 . The fear is that they may be subject to new regimes of prescription and exclusion on the basis of ethnicity, gender, sect, or ideological difference that oblige them once more to perform the passive and subordinate subject.

It remains to be seen whether these events represent the kind of shock that is both the outcome of significant, if gradual changes in the habitus, as well as the catalyst that allows new norms to establish themselves, calling forth significantly different performances. There were some who claimed, for instance, to have seen such changes as an immediate outcome of the gathering of a mass public in Tahrir Square in Cairo, visible not only in the care that people took of public property and public space, but also of each other in terms of respect for difference. In part this was planned, a deliberate construction of the square in January/February 2011 as a public theatre of civility, but it could also be seen in the ways in which people began to behave towards each other, promising, for the optimists, new norms, and possibilities in social life.

Powerful as these norms were at that moment and in that space, they have evidently dissipated somewhat the further people moved from the performative arena of Tahrir. It has clearly been the intention of many in Egyptian public life to ensure that the new institutions of the Egyptian state and the new rules for political life enshrine and reinforce those norms, securing them into the future by building them into the performance of the political. In this task, as the course of Egyptian politics since February 2011 has demonstrated, they are up against those who have other priorities, and who may see such performances as a threat to their own identities and interests. Most notoriously this has been embodied in the SCAF, but there are others, 
both within the Islamist trend and beyond it, who share their restrictive and regimented ideas about political performance, its permitted roles, and the actors allowed to play them.

In this respect, performances, like the politics of which they form a part, are never fixed, despite the best endeavors to make them so. For established and entrenched power, they hold out the promise of disciplining their subjects in ways that reinforce the status quo, blinding them to the scripted inequality of the roles they are expected to play. This can indeed work as intended for some considerable time, especially when reinforced by other imaginative and material inducements to conformity. However, like all performances they are also subject to decay. Gradually the roles become hollow, less meaningful, and finally less effective in staving off subversion and disruption. By the same token, insurgent forces, appropriating new theatres of action, acting in ways that challenge everything the status quo stands for, put their energies into ensuring that their radically different scripts will thenceforth shape public life. In the case of the uprisings of 2011 they succeeded in giving substance to the very role of the public itself for the first time in decades.

Now, in the aftermath of the overthrow of the dictators, the insurgents too face the challenge of ensuring that the moment of enthusiastic, even cathartic, performance, can be carried on into the institutions and practices of the new political order. As political developments in Egypt, Tunisia, Libya, and Yemen have shown, the uprisings have opened up a long and contentious period in which citizens will be trying various ways of giving substance to civility whilst encompassing the diversity that had emerged in the mobilized but plural publics of these countries. Precisely because the theatres of power have shifted, the roles and the performances are still being worked out. An uncertain balance exists between the spontaneous adlibbing that 
draws upon a repertoire challenging authority and the fully scripted roles that have

been mapped out by those who still control key institutional and coercive powers in

the state.

\footnotetext{
${ }^{1}$ Pierre Bourdieu, Outline of a Theory of Practice (Cambridge: Cambridge University Press, 1977); Judith Butler Excitable Speech: A Politics of the Performative (London: Routledge, 1997), 141-150. ${ }^{2}$ James C. Scott, Domination and the Arts of Resistance - Hidden Transcripts (New Haven, CT: Yale University Press, 1990).

${ }^{3}$ Jacques Rancière, Disagreement: Politics and Philosophy (Minneapolis: University of Minnesota Press, 1998).

${ }^{4}$ Joel Beinin, "A Workers' Social Movement on the Margin of the Global Neoliberal Order, Egypt 2004-2009," in Social Movements, Mobilization, and Contestation in the Middle East and North Africa, Joel Beinin and Frédéric Vairel, eds. (Stanford: Stanford University Press, 2011), 181-201; Anne Alexander, "Leadership and Collective Action in the Egyptian Trade Unions", Work, Employment and Society, 24/2 (June 2010), 241-259.

${ }^{5}$ Pierre Bourdieu, Language and Symbolic Power (Cambridge: Polity Press, 1991); Ernesto Laclau and Chantal Mouffe Hegemony and Socialist Strategy: Towards a Radical Democratic Politics (London: Verso, 1985); Rancière, Disagreement.

${ }^{6}$ Slavoj Žižek, For They Know Not What They Do: Enjoyment as A Political Factor. (London: Verso, 2002); Slavoj Žižek, The Parallax View (Cambridge: MIT Press, 2006); Lawrence Grossberg We Gotta Get Out of this Place: Popular Conservatism and Postmodern Culture (London: Routledge, 1992). ${ }^{7}$ John Chalcraft, "Horizontalism in the Egyptian Revolutionary Process," Middle East Report, 262 (Spring 2012), 6-11.

${ }^{8}$ Hogra [haqqara - to hold in contempt] is a term used in North African countries to express the contemptuous attitude of the authorities to their citizens. "We are all Khaled Said" was the Facebook page created by Egyptians outraged by the fate that befell Khaled Said in 2010-a young man seized by the security apparatus while he was investigating a case of corruption. He was beaten to death, his body dumped contemptuously on a street in Alexandria in full view of passersby.

${ }^{9}$ Jeffrey C. Alexander, Performative Revolution in Egypt: An Essay in Cultural Power (London: Bloomsbury Academic, 2011).

${ }^{10}$ Guy Debord, The Society of the Spectacle, D. Nicholson-Smith, trans. (New York: Zone Books, 1995), 12-13, 15-16.

${ }^{11}$ Erving Goffman, Interaction Ritual (Harmondsworth: Penguin, 1971); Erving Goffman, Encounters (Harmondsworth: Penguin, 1972); Žižek, For They Know Not What They Do; Butler, Excitable Speech, 160.

${ }^{12}$ Lisa Wedeen Ambiguities of Domination: politics, rhetoric and symbols incontemporary Syria (Chicago: Chicago University Press, 1999); Judith Butler "Bodies in Alliance and the Politics of the Street" (lecture in Venice, 7 September 2011) Transversal (webjournal). http://eipcp.net/transversal/1011/butler/en [accessed 8 May 2012].

${ }^{13}$ Louis Althusser "Ideology and Ideological State Apparatuses", in Lenin and Philosophy and Other Essays, Ben Brewster, trans., (New York, Monthly Review Press, 1971), 168; Michel Foucault, The Order of Things (London: Routledge, 2001).

${ }^{14}$ Rancière Disagreement.

${ }^{15}$ Seteney Shami, ed., Publics, Politics and Participation: Locating the Public Sphere in the Middle East and North Africa (New York: Social Science Research Council, 2009).

${ }^{16}$ Karima Khalil, Messages from Tahrir (Cairo: American University in Cairo Press, 2011).

${ }^{17}$ Richard Merelman, "The Dramaturgy of Politics," The Sociological Quarterly 10/2 (March 1969), 232-5.

${ }^{18}$ Jürgen Habermas "Towards a Theory of Communicative Competence" in Recent Sociology (No. 2.) Hans Peter Dreitzel, ed. (Toronto: Macmillan, 1970), 115-148.

${ }^{19}$ P.K. Manning, "Dramaturgy, Politics and the Axial Media Event", The Sociological Quarterly, 37/2 (March 1996), 262-6; T. R. Young \& Garth Massey "The Dramaturgical Society: a Macro Analytic Approach to Dramaturgical Analysis," Qualitative Sociology 1/2 (1978), 78-82, 92-3.
} 


\footnotetext{
${ }^{20}$ Sahar Khamis and Sarah Vaughn, "Cyberactivism in the Egyptian Revolution: How Civic Engagement and Citizen Journalism Tilted the Balance," Arab Media and Society, Issue 14 (Summer 2011), [accessed 12 February 2012] http://www.arabmediasociety.com/?article=769.

${ }^{21}$ Murray Edelman, Constructing the Political Spectacle (Chicago: University of Chicago Press, 1988), $1-3,112-5$.

${ }^{22}$ Khaled Elgindy, "Egypt's Troubled Transition: Elections without Democracy," Journal of Democracy 35/2, (2012), 89-104.

${ }^{23}$ Abner Cohen, Politics of Elite Culture: Explorations in the Dramaturgy of Power in a Modern African Society (Berkeley: University of California Press, 1981), 15-6, 155-6.

${ }^{24}$ Henry A. Giroux, Beyond the Spectacle of Terrorism: Global Uncertainty and the Challenge of the New Media (Boulder: Paradigm Publishers, 2008), 20-30

${ }^{25}$ Watha'iq Tahrir [Documents of Tahrir] [accessed 15 September 2012]

http://www.tahrirdocuments.org/2011/03/how-to-revolt/; David Kirkpatrick and David Sanger "A Tunisian-Egyptian Link that Shook Arab History," New York Times February 13, 2011.

${ }^{26}$ International Crisis Group, Popular Protest in the Middle East and North Africa (VI): The Syrian

People's Slow-Motion Revolution, MENA Report 108, July 6, 2011 [accessed 10 March 2012] http://www.crisisgroup.org/en/regions/middle-east-north-africa/egypt-syria-lebanon/syria.aspx ; International Crisis Group Popular Protest in the Middle East and North Africa (VII): The Syrian Regime's Slow-Motion Suicide, MENA Report 109, July 132011 [accessed 10 March 2012] http://www.crisisgroup.org/en/regions/middle-east-north-africa/egypt-syria-lebanon/syria.aspx .

${ }^{27}$ Salwa Ismail, "The Syrian Uprising: Imagining and Performing the Nation," Studies in Ethnicity and Nationalism, 11/3 (2011), 538-549.
}

Charles Tripp is Professor of Politics with reference to the Middle East, at the School of Oriental and African Studies, University of London. He is the author of: Islam and the Moral Economy: The Challenge of Capitalism (Cambridge University Press, 2006); A History of Iraq (Cambridge University Press, 2007). His most recent book is The Power and the People: Paths of Resistance in the Middle East (Cambridge University Press, 2013) 